\title{
PENDAMPINGAN PENGEMBANGAN KEWIRAUSAHAAN TANAMAN HIDROPONIK DI UNIVERSITAS MUSLIM NUSANTARA AL WASHLIYAH MEDAN
}

\author{
Ricky Andi Syahputra ${ }^{1^{*}}$, Bambang Hermanto², Alistraja Dison Silalahi ${ }^{3}$, Dian Habibie ${ }^{2}$

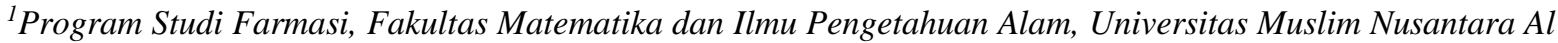 \\ Washliyah, Medan, Indonesia \\ ${ }^{2}$ Program Studi Agribisnis, Fakultas Pertanian, Universitas Muslim Nusantara Al Washliyah, Medan, Indonesia \\ ${ }^{3}$ Program Studi Akuntansi, Fakultas Ekonomi, Universitas Muslim Nusantara Al Washliyah, Medan, Indonesia \\ *Penulis Korespondensi: rickyandi0712@gmail.com
}

\begin{abstract}
Abstrak
Kegiatan ini merupakan implementasi dari Program Pengembangan Usaha Produk Intelektual Kampus (PPUPIK) yang befokus kepada inisiasi Agredusains di Universitas Muslim Nusantara Al Washliyah (UMN) Al Washliyah di Kota Medan. Program ini meliputi bidang Agribisnis, Edukasi dan Sains dengan pemanfaatan potensi sarana dan prasarana yang dimiliki oleh UMN Al Washliyah khususnya dalam bidang pertanian (rumah kasa) maka program ini melakukan pendampingan dalam mengembangkan tanaman hidroponik di Fakultas Pertanian. Program ini bertujuan untuk mempercepat program unggulan UMN Al Washliyah dalam bidang pertanian khususnya dalam budidaya tanaman. Tanaman hidroponik yang dikembangkan yaitu sawi botol. Metode pelaksanaan yaitu dimulai dari sosialisasi, perakitan rangkaian alat hidroponik, pembibitan hingga panen. Pembibitan dilakukan selama 2 minggu selanjutnya dilakukan pemindahan bibit pada media hidroponik kemudian dalam waktu 6-8 minggu sawi botol dapat dipanen. Sawi botol yang dihasilkan memiliki kualitas yang unggul yang dilihat dari kesuburan tanaman sawi botol.
\end{abstract}

Kata Kunci: Pendampingan, Agribisnis, Tanaman Hidroponik, Sawi Botol.

\begin{abstract}
This program is an implementation of the Campus Intellectual Business Development funded by the ministry of research, technology and higher education. This program covers the areas of Agribusiness, education and science. The potential infrastructure owned by Universitas Muslim Nusantara Al Washliyah in particular in the field of agriculture (House of gauze) then this program doing mentoring in developing a hydroponic plant at the Faculty Agriculture. The program aims to accelerate the program's flagship UMN Al Washliyah in agriculture particularly in cultivation. Hydroponic plants developed namely mustard bottle. The method of execution starting from assembling a series of hydroponic nursery, tools to harvest. The nursery is done during the next 2 weeks done the transfer of seedlings on hydroponic media then within 6-8 weeks the mustard bottle can be harvested. Mustard bottles produced has a superior quality that is seen from the fertility of crops mustard bottle.
\end{abstract}

Keywords: Mentoring, Agribusiness, Hydroponic Plants, Mustard Bottle.

\section{PENDAHULUAN}

Kewirausahaan atau enterpreneurship pada mulanya merupakan konsep yang dikembangkan dalam tradisi sosiologi dan psikologi. Enterpreneurship adalah suatu proses kreativitas dan inovasi yang mempunyai resiko tinggi untuk menghasilkan nilai tambah bagi produk yang bermanfaat bagi masyarakat dan mendatangkan kemakmuran bagi wirausahawan. Kewirausahaan merupakan kemampuan melihat dan menilai peluang bisnis serta kemampuan mengoptimalkan sumberdaya dan mengambil tindakan dan risiko dalam rangka mesukseskan bisnisnya terutama dari tanaman hidroponik.
Hidroponik merupakan teknik budidaya tanaman tanpa menggunakan media tanah, melainkan menggunakan air sebagai media tanamnya. Keuntungan hidroponik adalah tidak memerlukan lahan yang luas, mudah dalam perawatan, memiliki nilai jual yang tinggi sedangkan kelemahan hidroponik adalah memerlukan biaya yang mahal dan membutuhkan keterampilan yang khusus. Disamping itu juga kemampuan mahasiswa dalam mengembangkan tanaman hidroponik masih sangat rendah, hal ini disebabkan oleh berbagai faktor, antara lain yaitu: 
a. Para mahasiswa memiliki pemahaman yang lemah dalam mengembangkan usaha terutama dari tanaman hidroponik

b. Para mahasiswa menganggap melakukan kegiatan dari tanaman hidroponik ini adalah suatu pekerjaan yang sangat rumit dan sulit.

c. Perilaku dan Pola pikir mahasiswa yang belum terbiasa dan merasa belum mampu menghasilkan suatu produk terutama dari tanaman hidproponik

Berdasarkan hal tersebut, perlu dilakukan pembekalan dan penanaman jiwa entrepreneur pada mahasiswa sehingga dapat memotivasi mahasiswa untuk melakukan kegiatan kewirausahaan sehingga berkembanglah wirausahawan baru yang berhasil menciptakan kerja, sekaligus menyerap tenaga kerja, oleh sebab itu mahasiswa membutuhkan pendampingan dari dosen untuk menjadi seorang wirausahawan terutama dalam pemanfaatan tanaman hidroponik maka perlu adanya stimulus kepada mahasiswa melalui perencanaan hingga pendampingan pengembangan kewirausahaan tanaman hidroponik.

\section{METODE PELAKSANAAN KEGIATAN PENDAMPINGAN PENGEMBANGAN KEWIRAUSAHAN}

\subsection{Waktu Dan Tempat}

Kegiatan pengabdian dilakukan di rumah kasa Fakultas Pertanian UMN Al Washliyah medan melalui Program Pengembangan Usaha Produk Intelektual Kampus (PPUPIK) 2018 (Syahputra, dkk, 2018). kegiatan itu berlangsung pada bulan April - Oktober 2018.

\subsection{Kegiatan Pengabdian Pendampingan Pengembangan Kewirausahaan}

Kegiatan pengabdian pendampingan pengembangan kewirausahaan yaitu dimulai dari pembuatan rangkaian alat hidroponik, pembibitan hingga panen. Pembibitan dilakukan selama 2 minggu selanjutnya dilakukan pemindahan bibit pada media hidroponik kemudian dalam waktu 6-8 minggu sawi botol dapat dipanen.

\subsection{Pelaksanaan Kegiatan Pendampingan Pengembangan Kewirausahaan}

Kegiatan Pengabdian Pendampingan Pengembangan Kewirausahaan ini dilakukan dalam 2 (dua) tahap, yakni tahap pertama pembuatan rangkain alat tanaman hidroponik. Tahap kedua yaitu melakukan pembibitan dan pemanenan sawi botol.

a. Pembuatan rangkaian alat tanaman hidroponik Proses produksi sawi botol dilakukan di rumah kasa fakultas pertanian dengan menggunkan metode hidroponik sitem DFT. Prinsip kerja dalam system deep flow technique (DFT) ini adalah mensirkulasi larutan nutrisi tanaman secara terus menerus selama 24 jam dalam rangkaian aliran air tertutup. Larutan nutrisi yang ada dalam tangki akan dipompa menuju bak - bak penanaman melalui pipa - pipa irigasi, lalu larutan nutrisi tersebut akan dialirkan kembali menuju tangki (Wirawan dkk, 2014).
Kelebihan Bertanam Hidroponik Sistem Deep Flow Technique:

Sistem Deep Flow Technique (DFT) ini memiliki kelebihan diantaranya adalah, pada saat aliran listrik padam lautan nutrisi akan tetap tersedia untuk tanaman, karena dengan menggunakan system ini larutan nutrisinya mencapai di kedalaman $6 \mathrm{~cm}$. Selain memiliki kelebihan, teknik bercocok tanam hidroponik sistem deep flow ini juga memiliki kekurangan. Lalu untuk kekukarangannya adalah, system ini membutuhkan larutan nutrisi lebih banyak dibandingkan dengan system Nutrient Film Technique.

Alat:

1. Hand Bor,

2. Satu set Hole Saw,

3. meteran,

4. penggaris,

5. cutter,

6. gergaji besi,

7. spidol,

Bahan:

1. Pipa 3"

2. Dop 3"

3. Soket pipa $3 "-1 "$

4. Elbow 1"

5. Pipa $1 "$

6. Pipa $1 / 2 "$

7. Besi siku

8. Container

9. Mesin aquarium

Prosedur kerja:

- Setelah semua pipa selesai dipotong sesuai dengan ukuran pada tabel langkah selanjutnya adalah melakukan pengeboran untuk membuat lubang pada pipa 3" yang nantinya akan dijadikan tempat untuk netpot.

- Siapkan holesaw ukuran 44mm (sesuaikan dengan ukuran netpot yang akan Anda gunakan) dan juga hand bor.

- Lalu ambil pipa 3" yang sudah dipotong dan mendapatkan ukuran $95 \mathrm{~cm}$, kemudian ambil garis lurus dari ujung sampai ke ujung dengan menggunakan meteran.

- Seperti yang Anda lihat pada gambar diatas selain garis lurus saya juga menyiapkan 2 garis lainnya yaitu diujung sebelah kiri dan kanan dengan ukuran $2.5 \mathrm{~cm}$, mengapa harus dilakukan karena nanti kedua lubang pipa ini akan ditutup oleh Soket/dop, oleh karena itu dalam pengambilan ukuran untuk titik pengeboran hole saw dimulai dari garis tersebut.

- Langkah selanjutnya adalah membuat lubang untuk netpot, setelah garis lurus dan juga garis penanda dop dikiri dan dikanan pipa selesai dibuat selanjutnya adalah membuat lubang dengan jarak lubang sejauh $20 \mathrm{~cm}$ antara lubang satu dan lainnya dengan membuat tanda yaitu berupa titik disetiap 20 $\mathrm{cm}$ pengukuran di pipa tersebut dengan spidol

- Setelah semua titik selesai dibuat langkah selanjutnya adalah melakukan pengeboran satu persatu di setiap titik yang sudah dibuat dengan 
menggunakan hand bor dan juga hole saw yang sesuai dengan netpot.

- Kemudian gantung pipa di dinding dengan besi siku

- Lalu pasang Soket pipa 3"-1" disetiap ujung pipa kemudian sambung dengan elbow 1" untuk mengalirkan air ke pipa bawah.

- Isi air pada countainer hingga penuh, setelah itu pasang mesin aquarium dalam countainer dan pasang pipa $1 / 2$ " sebagai penghubung antara mesin aquarium dan hidroponik kit.

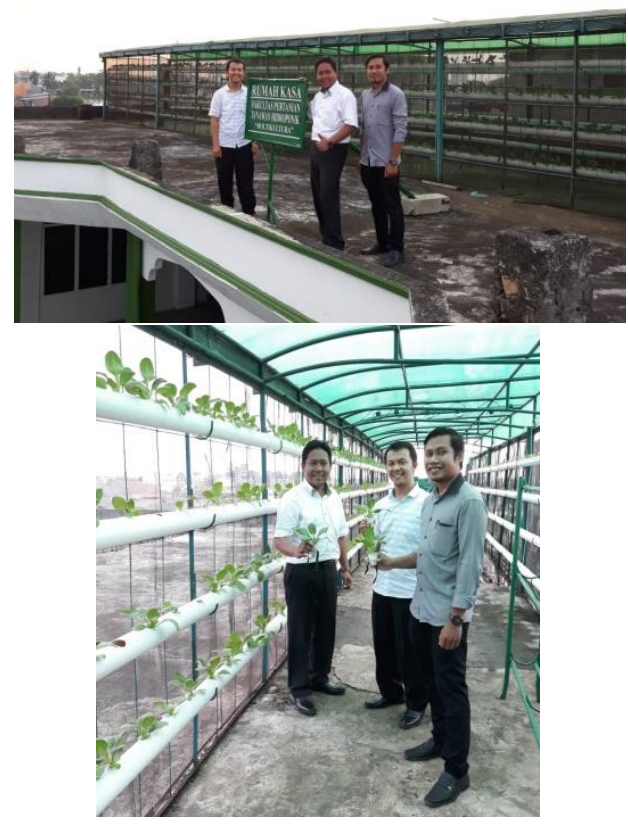

Gambar 1. Rumah kasa dan rangkaian alat tanaman hidroponik.

\section{b. Pembibitan dan pemanenan sawi botol}

Kegiatan pada tahap kedua yakni melakukan pembibitan dengan langkah-langkah sebagai berikut:

Bahan :

1. Semai tray

2. Rockwool

\section{Cara Semai Benih:}

1. Rendam benih selama \pm 1 jam

2. Potong rockwool bentuk dadu, dengan ukuran $(2 \times 2$ x 2) $\mathrm{cm}^{3}$, dan letakkan di atas semai try

3. Buat lubang sedalam $1 \mathrm{~cm}$ di permukaan potongan rockwool!

4. Taruh benih ke dalam lubang

5. Basahi rockwool dengan air sampai lembab! !! Jangan terlalu basah!!

6. Letakkan di tempat yang terkena cahaya matahari tidak langsung.

7. Tanaman siap dipindah setelah memiliki 4 daun

Catatan :

Usahakan selalu lembab, dengan menyemprotkan air saat pagi dan sore selama masa semai. Setelah muncul daun, pastikan daun terkena matahari langsung (Ningrum, 2014).

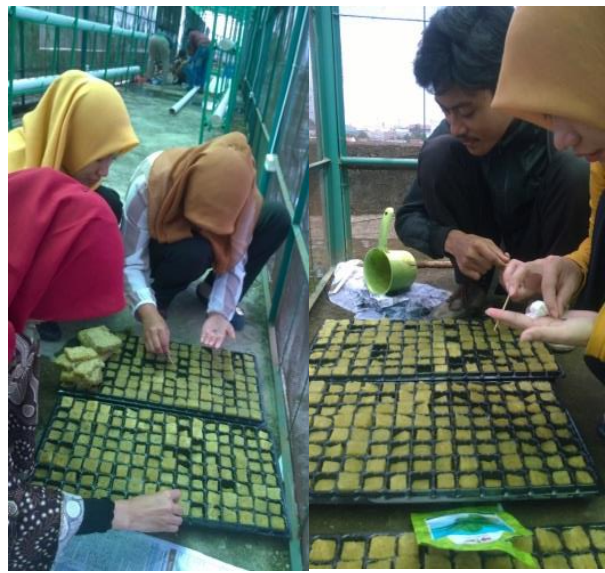

Gambar 2. Proses penyemaian bibit Sawi Botol oleh Mahasiswa pertanian UMN Al Washliyah.

\section{Cara Memindah Benih Ke Rak Hidroponik:}

a. Pindahkan Tanaman dengan memegang rockwool ke dalam netpot dengan hati-hati.

b. Letakkan seledri dalam netpot ke dalam lubang PVC.

c. Alirkan larutan nutrisi ke dalam pipa PVC. (Ningrum, 2014).

\section{Proses Pemanenan tanaman hidroponik}

Sawi botol yang telah disemai dan dipindahkan, setalah 8 minggu dapat dipanen. Dalam proses pemanenan tanama sawi botol secara hidroponik dapat dilakukan dengan mudah, yaitu dengan mencabut tanaman dari pot hidroponik. Adapun gambar suasana rumah kasa setelah sawi botol tumbuh dapat dilihat pada gambar berikut:

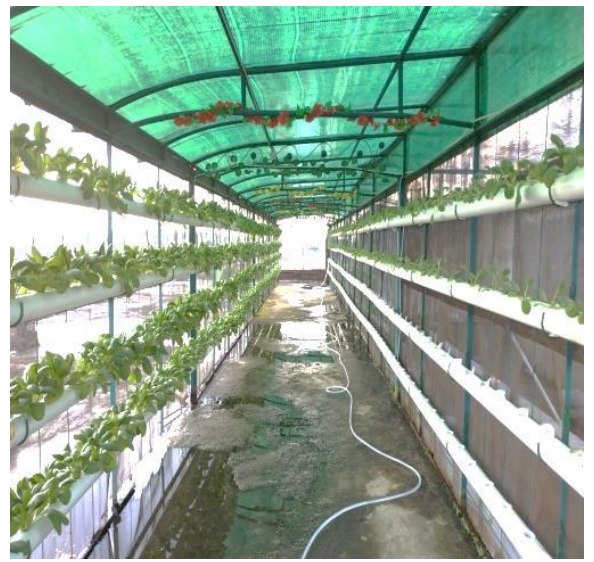

Gambar 3. Suasana ruangan hidroponik sawi di rumah kasa.

Setelah tanaman hidroponik sudah layak dipanen, dekan Fakultas Pertanian membuat acara panen raya dalam rangka untuk meningkatkan minat mahasiswa dalam pengembangkan tanaman hidroponik dan menumbuh kembangkan jiwa kewirausahaan dalam bidang tanaman hiroponik. Adapun dokumentas kegiatan panen raya UMN Al Washliyah dapat dilihat pada gambar berikut: 


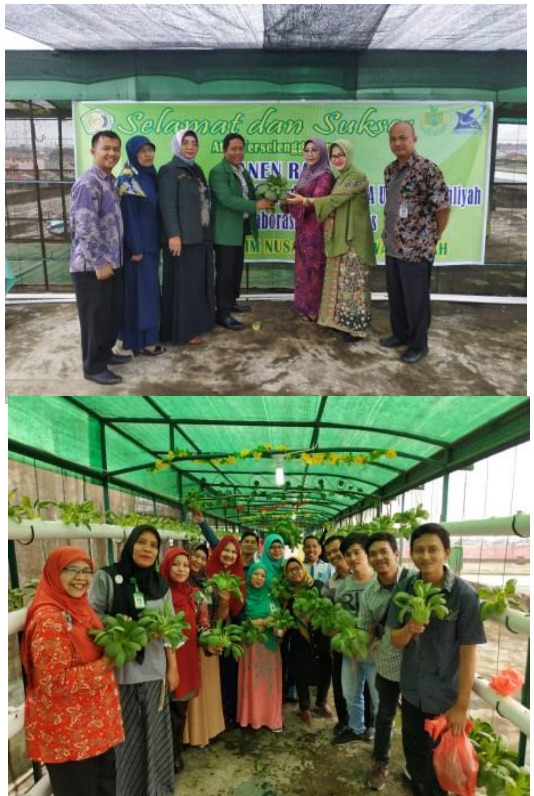

Gambar 4. Panen Raya UMN Al Washliyah.

Panen raya yang dilkukan Fakultas Pertanian yang bekerja sama dengan Fakultas Matematika dan Ilmu Pengetahuan Alam (Farmasi) yang dihadiri oleh jajaran Rektorat dan Dekanat UMN Al Washliyah, PB Al Washliyah dan Perwakilan oleh Ibu Sekretaris Pelaksana LLDIKTI Wilayah 1. Dalam Pelaksanaan ini, Ibu Sespel LLDIKTI wilayah 1 mengapresiasi semangat jiwa kewirausahaan mahasiswa (Hanum, dkk, 2018) khususnya dibidang tanaman hidroponik dimana tanaman sawi botol yang dihasilkan berdaun besar-besar, tinggi dan segar-segar.

\section{KESIMPULAN}

Berdasarkan kegiatan yang telah dilakukan maka dapat disimpulkan bahwa peningkatan jiwa kewirausahaan mahasiswa dapat dilakukan dengan melakukan pendampingan terhadap mahasiswa. Kegiatan ini juga menghasilkan media hidroponik yang dapat digunakan sebagai wadah pengembangan tanaman hidroponik di UMN Al Washliyah. Kegiatan ini juga dapat menggerakan ekonomi mahasiswa yang bekerja sama dengan pihak kampus dalam pemasarannya. Kegiatan ini juga dapat mengedukasi mahasiswa khususnya mahasiswa pertanian dalam mengaplikasikan ilmu pertaniannya.

\section{UCAPAN TERIMA KASIH}

Ucapan Terima kasih kepada DRPM Kemenristek Dikti melalui Program Pengembangan Usaha Produk Intelektual Kampus Tahun 2018 dan Rektor Universitas Muslim Nusantara Al Washliyah atas bantuan berupa materi, sarana dan prasarana dalam kegiatan pengabdian kepada Masyarakat.

\section{DAFTAR PUSTAKA}

Hanum, S.F., Tiara, S., dan Samran, 2018, Tenant PKK UMN Al Washliyah dalam Mengembangkan Kewirausahaan, Amaliyah: Jurnal Pengabdian Kepada Masyarakat, Vol. II, No. 2, Hal: 184188.
Ningrum, D.Y., Triyono, S., Tusi, A., 2014, Pengaruh Lama Aerasi Terhadap Pertumbuhan Dan Hasil Tanaman Sawi (Brassica juncea L.) pada Hidroponik DFT (Deep Flow Technique), Jurnal Teknik Pertanian Lampung, Vol.3, No. 1: $83-90$

Syahputra, R.A., Hermanto, B., dan Silalahi, A.D., 2018., Hilirisasi Produk Intelektual Kampus Universitas Muslim Nusantara Al Washliyah Pada Bidang Farmasi, Prosiding PKM-CSR Vol. 1, e-ISSN: 2655-3570. Hal. 1395-1400.

Wirawan, A.W., Wirosoedarmo, R., dan Susanawati, L. D., 2014., pengolahan limbah cair domestik Menggunakan tanaman kayu apu (pistia stratiotes 1.) Dengan teknik tanam hidroponik sistem DFT

(Deep Flow Technique). Jurnal Sumberdaya Alam dan Lingkungan., Vol. 1. No. 2. Hal. 6370 